J. Dairy Sci. 95:1585-1585

http://dx.doi.org/10.3168/jds.2012-95-3-1585

(C) American Dairy Science Association ${ }^{\circledR}, 2012$.

\title{
Erratum to "Reduction of pasteurization temperature leads to lower bacterial outgrowth in pasteurized fluid milk during refrigerated storage: A case study" (J. Dairy Sci. 95:471-475)
}

\author{
N. H. Martin, M. L. Ranieri, M. Wiedmann, and K. J. Boor
}

The authors wish to correct an error that appeared in their recent Our Industry Today article. On pages 471 and 472 , the temperature of pasteurization in degrees Fahrenheit was misstated. The authors note that $79.4^{\circ} \mathrm{C}$ is $175^{\circ} \mathrm{F}$, not $185^{\circ} \mathrm{F}$ as originally stated. The authors apologize for this error.

\section{REFERENCES}

Martin, N. H., M. L. Ranieri, M. Wiedmann, and K. J. Boor. 2012. Reduction of pasteurization temperature leads to lower bacterial outgrowth in pasteurized fluid milk during refrigerated storage: A case study. J. Dairy Sci. 95(1):471-475. 